moment of Jesus's death, the Jews onstage donned yellow badges marked with Stars of David, suggesting the legacy of anti-semitism linked to this pivotal moment in history. Strikingly, John stepped into the action at this point and also inscribed Caiaphas's tablet badge with a Star of David. Despite the moment's bracing anachronism and interpolated quality, it did not detract from the emotional force of the scene that immediately followed. The centurion's conversion was startlingly powerful, and emblematic of the intelligence and sensitivity with which the Graduate Study for the Centre of Drama produced this play.

Dimitry A. SENYShyn

Notes

1 Melvyn Bragg and Norman Jewison, Jesus Christ Superstar, directed by Norman Jewison (Universal City, CA: Universal Pictures, 1973), Theatrical Release.

\title{
'The Ascension': Blood and Roses
}

Day two of Chester 2010 was about Jesus's presence. The audience saw Jesus as a baby (doll), a young man, and an adult; at the end of the day, during 'The Crucifixion', Jesus's bleeding or dead body was emphatically there, sometimes within inches of the audience. His presence on day three, however, was problematic. Is his body in the grave at 'The Resurrection'? Is the body on stage in 'The Antichrist' that of Christ or the Antichrist? The opening and closing plays on day three are also chaotic and noisy, with large casts spilling over to the surrounding ground. Three central plays, however — 'The Road to Emmaus', 'The Ascension', and 'The Pentecost' - confront this issue of presence and absence with a serenity that embraces but ultimately conquers the human anxiety of the faithful on stage and in the audience. Chester 2010's 'The Ascension' (directed by dance and drama professor Artemis Preeshl, with additional coaching by English professor John Sebastian, both of Loyola University New Orleans) captured the constantly shifting moods of despair, anxiety, hope, and confidence that the play represents. Jesus absents himself through his ascension, but also remains as a real yet 


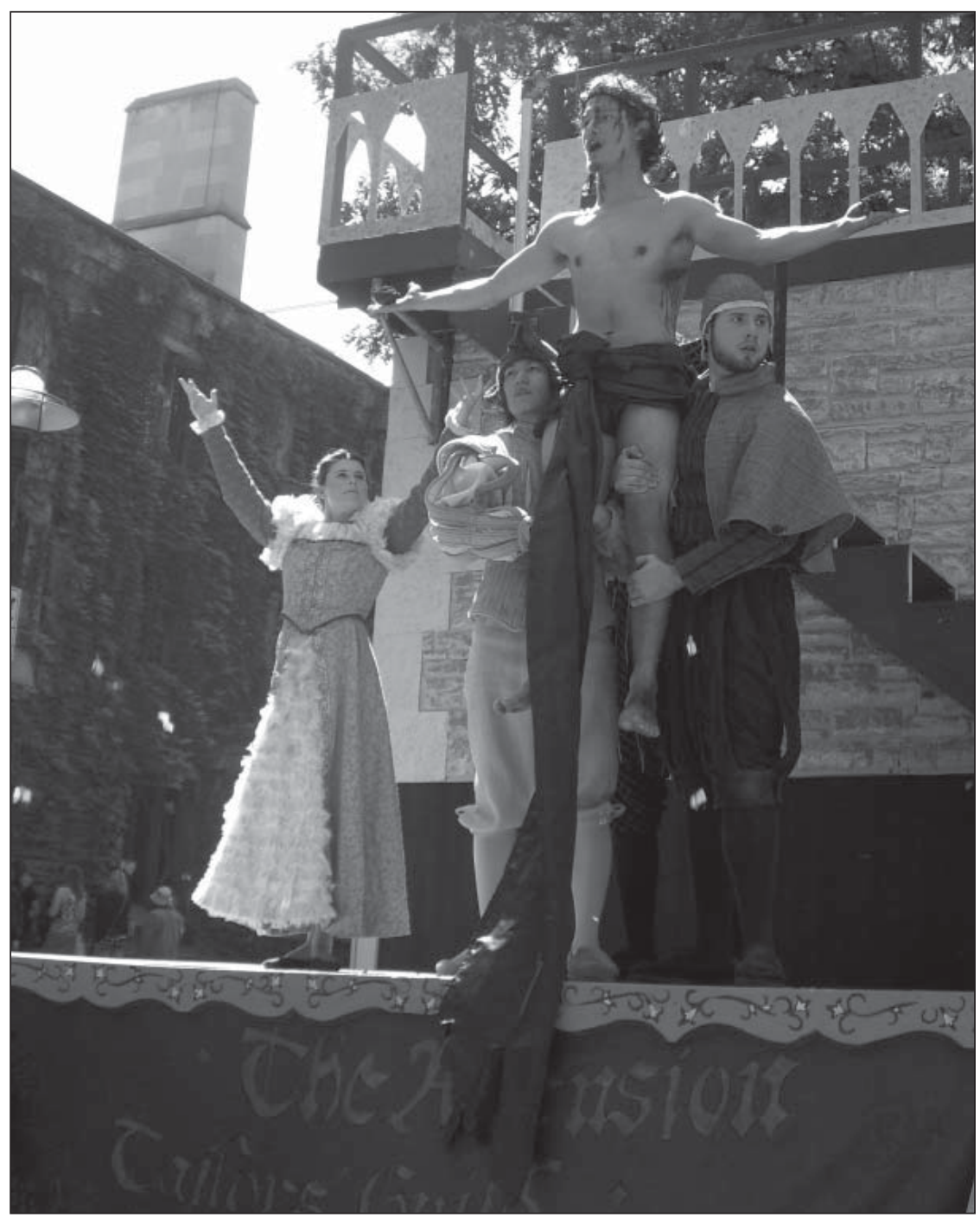

Fig. 9. 'The Ascension' (Loyola University). Courtesy of Heather S. Mitchell.

no longer physical presence for his faithful followers in the sixteenth- and twenty-first-century worlds of the audience as well as for the dramatic characters of the first century.

The apostles and angel were dressed in extravagant sixteenth-century costumes, befitting a play that the Tailors originally produced. Jesus, who will 
soon exit the realm of earthly time, was naked except for bloody wounds and a blood-red silk loin-cloth extending into a long (at least eight foot) swath of fabric trailing to the earth. Although the script calls for six apostles and four angels, the performance in Toronto included only three apostles and one angel. Rather than detract from the performance, however, the use of a smaller cast allowed the actors the space to move in a slow, deliberate pace, and for meaningful gestures to register with the audience. For instance, the apostles often had their hands in prayer reaching upward and forward diagonally, rather than straight up, signalling reverence but also longing. The open arms of Jesus, showing his wounds and willingness to suffer, were subtly different from the open arms of the apostles, revealing confusion or gratitude. Because the movement was not naturalistic but ritualistic and dance-like, a gesture would often end in brief stillness, almost as if time were stopping, reflecting Jesus's imminent departure from the world of time and entrance back into eternity.

The stage directions in the text call for Jesus to ascend in a sequence of upward movements, probably by means of some kind of machinery. In Toronto, Jesus started to ascend the stairs of the 'God-above' tower, but then returned to the stage, to earth, to talk with his apostles rather than to the angels as he was ascending. As he spoke to them, the apostles re-enacted the history of salvation: the fall, the last supper, the scourging, and the crucifixion. The apostle John literally fell into the arms of the other apostles when Jesus described how the devil brought the 'great danger' of the fall to Adam (78). Two apostles lifted Jesus, who formed a cross with his arms when he described how he 'died for Man on the rood-tree' (86). Such gestures suggested that Jesus was imprinting the history of salvation on his followers' memories one more time, in his presence, with their bodies and his, before his final departure, almost as if the longing for presence were his as much as theirs. When he finished his speech, he again started to ascend, but did not totally disappear from the audience. While the apostles painfully lamented his absence and at the same time encouraged and comforted one another, the blood-red silk of Jesus's train was visible to the audience from behind the angel, halfway up the stairs, a reminder to the audience that although Jesus is no longer physically present he and his saving blood remain present for 'good men ... on earth' (91).

The most beautiful symbols for Jesus's simultaneous absence and presence in Loyola's 'Ascension' were the roses. The actor playing Jesus had stage blood on his side, face, and hands, but when the apostles lifted Jesus to represent the 
crucifixion, the stigmata in his palms had become roses without thorns, and the blood that he shed now became rose petals. When the play was over and the wagon was being pulled to the next station, the rose petals remained on the earth as a final reminder of Jesus's continuing presence.

Mary Elizabeth Ellzzey

\section{'Your saviour nowe in your sight': Vassar College's 'Coming of the Antichrist'}

'Prophets of the Antichrist' concludes with the Expositor declaring 'he comes - soon you shall see' (340), so audiences are unlikely to be baffled for long about the identity of the character in 'Coming of the Antichrist' who claims to be 'Christus, vester Salvator' (9). While the play-text strongly suggests that medieval and Elizabethan performers presented the Antichrist as a figure whom the audience could momentarily mistake for Jesus, the Vassar students working under the direction of English professor Dorothy Kim made production choices that allowed for no doubt that their Antichrist was demonic, not divine. In other ways, though, their performance demonstrated that this play - the only medieval English Antichrist play - confronted its audiences with the challenge of favouring true faith over outward shows of piety, wealth, and power.

The production alluded to the play's original connection to the Dyers guild by conspicuously employing colourful, rich-looking fabric. Costumes for the kings, the Antichrist, and the Antichrist's chief counsellor suggested an Elizabethan-era performance by relying on doublets and hose. The Antichrist (played by Callie Beusman) was a stylized cross between the devil as depicted in Lutheran pamphlets, complete with furry tail and codpiece, and the Whore of Babylon, flaunting scarlet lips and a bare belly. Her beauty and charisma explained her power over the two kings (Michael Masure and Gwendolyn Collaco). The miracles this Antichrist performed never seemed more than stage tricks as they were carried out with theatrical aplomb, yet they managed to echo in parodic ways those Jesus undertook in other Chester plays. For instance, while the figures the Antichrist raised from the dead (Nick Greenberg and Ashlei Hardenburg) seemed monstrous because of 